\title{
- ФЕНОМЕН КУЛЬТУРНО-ДОЗВІЛЛЄВОЇ ДІЯЛЬНОСТІ: КОНЦЕПТУАЛІЗАЦІЯ ПРОБЛЕМИ
}

\section{- Шмаюн Ольга Юріївна}

\section{- Аспірантка,} ORCID: 0000-0002-1863-3581, e-mail: olinka.fedorenko@gmail.com, Київський національний університет культури і мистецтв, вул. Є. Коновальця, 36, Київ, Україна, 01133

\section{- Для цитування:}

Шмаюн, О.Ю. (2021). Феномен культурно-дозвіллєвої діяльності: концептуалізація проблеми. Питання культурології, (38), 354-362. doi: https://doi.org/10.31866/2410-1311.38.2021.247184.

\section{- Анотація}

У статті досліджується феномен дозвілля як унікальне явище, яке сприяє реалізації та розвитку численних видів і форм культурно-дозвіллєвої діяльності. Мета статті дослідження особливостей розвитку сучасних культурно-дозвіллєвих центрів України в середовищі соціокультурного існування. Методологічною основою дослідження стали основні положення культурології, соціології культури та соціальної психології, які розглядають дозвіллєву культуру як соціокультурний феномен. Наукова новизна полягає у визначенні та уточненні науково-теоретичних підходів до вивчення дозвілля в рамках зарубіжних і вітчизняних дослідницьких робіт. Висновки. Аналіз процесу формування і становлення феномену культурно-дозвіллєвої діяльності спонукає до пошуку нових оптимальнихшляхів удосконаленнядіяльності культурно-дозвіллєвихцентрів. Формування нових суспільних відносин актуалізує дослідження проблем соціокультурної сфери, де культура відчуває вплив соціально-політичних і соціально-економічних механізмів, водночас безпосередньо впливаючи на їх розвиток, та стає своєрідним соціальним каталізатором. Зокрема, філософські аспекти дозвілля визначають його самодостатнім функціонуючим організмом. Відбулася також активізація наукових розробок педагогіки дозвілля, обґрунтування понятійного апарату, принципів, функцій, основних видів та організаційних форм, які використовуються у практиці його проведення. Соціальнопедагогічний аспект дозвільної діяльності знаходить своє відображення в інфраструктурі, змісті, дозвіллєвих вподобаннях для об'єднання різних рівнів організації соціального середовища. Наголошено, що глобалізація, посилення конкуренції, поглиблення інформаційних процесів призвели до цілеспрямованого характеру розвитку культурнодозвіллєвих центрів, адже рівень розвитку держави в сучасному світі оцінюється, у тому числі, й за діяльністю культурно-дозвіллєвих закладів.

Ключові слова: дозвілля; вільний час; культурно-дозвіллєва діяльність; інтерес 


\section{Вступ}

Вплив культури як життєво необхідного соціального феномену активно поширюється на дозвілля, адже воно є реальним часом для духовного розвитку особистості, зміцнення морального і фрізичного здоров'я, вдосконалення творчих здібностей людини. Соціально значуще дозвілля існує в рамках духовності, мистецтва, творчості, прагнення людей до саморозвитку та самовдосконалення. Невід'ємною складовою сучасної культури і вираженням інтересів соціуму $€$ культурно-дозвіллєві центри, спрямовані на реалізацію та примноження гуманних установок суспільства по забезпеченню проведення вільного часу молоді у приємній, сформованій за інтересами сфрері, що розвивається.

Філософські аспекти дозвілля у контексті розуміння проведення вільного часу в рамках культурної сфери з її складовими частинами та фрормами розглядались як закордонними, так і вітчизняними науковцями. Зокрема, Г. В. Гегель, А. Н. Уайтхед, Ф.В.Шеллінг, розглядаючи фрілософрські аспекти культурно-дозвіллєвих явищ, вважали їх складовими часового простору, що є цілісним, самодостатнім функціонуючим організмом. У дослідженнях А. К. Уледова, П. А. Флоренського, М. С. Кагана (1996), А. Ф. Лосєва, Е. С. Маркаряна (2000), Е. В. Соколова (1989) культурно-дозвіллєва діяльність визначається як творча робота, що виконується з метою отримання задоволення.

Розуміння суті і природи соціально-культурної діяльності та її ролі як суспільно значущої і морально-мотивованої діяльності по створенню, освоєнню, збереженню, поширенню і подальшому розвитку цінностей культури в житті суспільства описували М. А. Аріарський (Ариарский, 2008), Г. М. Бірженюк, Т. Г. Кисельова та Ю. Д. Красильников (2004), М. Ф. Максютін (Максютин, 2003), І. А. Новікова (Новикова, 1992).

Дослідження, проведені Г. О. Пруденським, С. Г. Струміліним, І. В. Бестужевим-Ладою (1997), В. О. Ядовим (1986), спираються на розуміння дозвілля як діяльності, яка характерна лише для реалізації у вільний час із метою отримання максимальної користі для окремого індивіда, що забезпечує рекреацію і подальший розвиток особистості.

\section{- Мета статті}

Мета статті - дослідження особливостей розвитку сучасних культурно-дозвіллєвих центрів України в середовищі соціокультурного існування. Методологічною основою дослідження стали основні положення культурології, соціології культури та соціальної психології, які розглядають дозвіллєву культуру як соціокультурний феномен. Наукова новизна полягає у визначенні та уточненні науково-теоретичних підходів до вивчення дозвілля в рамках зарубіжних і вітчизняних дослідницьких пошуків.

\section{Виклад матеріалу дослідження}

Сьогодні френомен культурно-дозвіллєвої діяльності став об'єктом особливої уваги в контексті розгортання фрілософського, соціологічного, культурологічного, психологічного та педагогічного напрямків. Сучасні вітчизняні та закордонні дослідження свідчать про те, що дозвіллєві центри не є надто чисельними, 
і тому при вивченні цього соціального явища виникають різного роду теоретикометодологічні проблеми (Бочелюк В. Й. \& Бочелюк В. В., 2006). Крім цього, сфрера дозвілля та культури швидко реагує на нові проблеми суспільства, що вважались раніше ґрунтовно вивченими. Така унікальність історичної ситуації постійно відтворює об'єктивну новизну зазначеного процесу, вимагає соціального осмислення проблем дозвілля і спонукає до його подальшої теоретичної розробки та удосконалення.

Поняття «дозвілля» має різні інтерпретації. Сучасні науковці визначають дозвілля як: систему занять у період особистого вільного часу, за допомогою яких задовольняються безпосередні потреби, як фрізичні, психічні, так і духовні, що в основному мають відновлювальний характер (Бочелюк В. Й. \& Бочелюк В. В., 2006); процес, що передбачає вільний час, орієнтований на створення умов для раціональної організації дозвілля населення в закладах культурнодозвіллєвої діяльності (Жаркова, 2015); спосіб використання людиною свого вільного часу з метою спрямування його на розвиток власних творчих здібностей, удосконалення культури спілкування, вмінь та навичок, що реалізуються в повсякденному житті (Петрова, 2011); вільний час, який залежить від ролі впливу фракторів людського потенціалу, що сприяє розподілу інтересів населення в різних сфрерах їх діяльності (Піча, 1990; Царьов \& Соколовський, 2011).

Зазначимо, що сьогодні дозвілля стає все більш комфортним, оскільки забезпечується розвитком технічного прогресу. В результаті ця проблема набуває нових граней, які не можна не враховувати при розгляді ролі й місця установ культури в організації культурно-дозвіллєвої діяльності населення.

Сьогодення детермінує певні напрямки в організації сфрери дозвіллєвих послуг для населення України. За допомогою глобальних інформаційних систем поширюються західні моделі дозвіллєвої діяльності, що впливають на зміст і спрямованість функціонування культурно-дозвіллєвих центрів. У сфрері дозвілля перехрещуються інтереси особистості і суспільства. Якщо молода людина безпосередньо не працює у сфрері культури, не займається нею професійно, то вона фрактично не має нічого, окрім дозвіллєвого часу, для власного культурного волевиявлення. Тому молодь посідає значне місце в розбудові культурнодозвіллєвих центрів, їх появі, подальшому удосконаленні за вподобаннями та інтересами і територіальному розширенні.

Як соціальний феномен дозвілля є унікальним явищем, що сприяє реалізації та розвитку численних видів і форм культурно-дозвіллєвої діяльності. Воно сприяє духовному формуванню людини, розвитку різносторонніх інтересів, створенню тісних зв'язків між ії учасниками.

Наголосимо, що дозвіллєва складова у сфері відпочинку і проведення вільного часу є частиною культурного становлення та розвитку держави, яка відображається в її установах, цілях, функціях, принципах і спрямована на розробку стратегій та завдань у сорері вільного часу суспільства. Кожна держава визначає власні аспекти розвитку культурно-дозвіллєвої діяльності відповідно до економічних, політичних, соціальних, культурних завдань. Дозвілля є також однією із ключових одиниць культурної сфери країни, проблема якої розглядається у теоретичному і практичному розуміннях, оскільки рівень розвитку суспільства вимірюється не 
лише характером виробництва продукції матеріальних благ, а в більш широкому значенні - організованою культурно-дозвіллєвою діяльністю населення.

Зміни у проведенні молоддю вільного часу спричинили активізацію наукових розробок із педагогіки дозвілля, обґрунтування понятійного апарату, принципів і функцій, основних видів та організаційних фрорм, які використовуються у практиці проведення дозвілля у закладах України, оскільки в дозвіллі вони не обмежені зовнішніми чинниками і залежать лише від своїх внутрішніх бажань та уподобань (Воловик А. Ф. \& Воловик А. В., 1999, с. 311). Таким чином, дозвіллєва діяльність не може функціонувати без внутрішніх установок особистості, яка задовольняє або, навпаки, заперечує особистісні потреби, саморозвиток та реалізацію своїх вподобань.

Важливим етапом на шляху організації дозвіллєвої діяльності для молоді $€$ створення відповідного середовища, в якому культура та мораль існуватимуть не самі по собі, безвідносно до життєвих потреб особистості, але входитимуть у життєвий простір індивіда і набуватимуть для нього особистісного сенсу, вдосконалення чи опанування різних сфер суспільної діяльності, життєвої необхідності, вироблення норм практичної поведінки (Цимбалюк, 2000).

Зазначимо, що протягом другої половини XX століття в розвинених країнах світу соціально-економічні зрушення вплинули на різні сфери людської життєдіяльності, у тому числі й на феномен дозвілля, оскільки в цей час сформувалась економічна фрункція, яка була поштовхом до створення сучасної індустрії дозвілля. Результатом цього стало масове споживання, що призвело до прибутковості, і ця індустрія увійшла до першої десятки найприбутковіших галузей світової економіки, посівши в різних країнах від 3-го до 9-го місця.

Отже, у наукових розробках із теорії і практики культурно-дозвіллєвої діяльності було реалізовано спробу виділити види дозвілля за конкретними характеристиками. Становлення дозвільної сфери пов'язано з економічним та політичним прогресом у країнах: існують можливість зарубіжних поїздок, потік кінопродукції Голлівуда, руйнування державної дозвіллєвої інфраструктури, її комерціалізація. На сучасному етапі популярними стають індивідуальні фрорми дозвіллєвої практики (Гриценко, 2001, с. 30).

Водночас на сьогоднішній день в Україні є значні проблеми в дозвільній діяльності, що виникають під час вибору дозвілля, оскільки необхідно розвивати інфраструктуру, удосконалювати зміст проведення дозвілля, впроваджувати програми його розвитку задля залучення різних категорій населення. Сфрера дозвілля в наш час трансформується та розглядається в загальнолюдських масштабах, відбувається глобалізація в межах регіону (європейська інтеграція), країни (національний характер), регіону країни (схід - захід), масштабах місця проживання (місто - село, промислові центри). Соціально-педагогічний аспект дозвільної діяльності знаходить своє відображення в інфраструктурі, змісті, дозвіллєвих вподобаннях, під час нього об'єднуються цінності різних рівнів організації соціального середовища (Бойко, 2011, с. 14).

Завдяки соціально-педагогічному напряму уможливлюються популяризація інноваційних видів дозвілля, збереження традиційних фоорм дозвільної діяльності та підвищення їхнього рівня організації, покращується інфраструктура 
дозвільного простору, а також збільшується доступність до дозвіллєвої сфе-ри. Сьогодні культурно-дозвіллєві центри є основним місцем зосередженості соціально-культурної діяльності людей у сфері дозвілля, де кожен здобуває навички самореалізації, самовдосконалення у творчості. Працівники культурнодозвіллєвих центрів піклуються про якісне поліпшення змісту і форм діяльності цих закладів та створення позитивного культурно-дозвіллєвого середовища шляхом інновацій, відмовившись від буденності, одноманітності і шаблонності культурно-дозвіллєвих фоорм, в основі діяльності яких стають структура та характер запитів людини, дотримуючись зауважень і побажань кожного відвідувача, постійно прагнучи розробляти та включати у практику нові, нетрадиційні і нестандартні форми розваг, освіти, спілкування і творчості різних верств населення (Азарян \& Мартынов, 2013).

\section{- Висновки}

Отже, однією з головних сфер життєдіяльності людини є культурно-дозвіллєва сфера, в якій відбуваються ії̈ всебічний розвиток, виховання та становлення як особистості з широким діапазоном кругозору та розгорнутою мережею знань. Продемонстровано, що процес фрормування і становлення феномену культурно-дозвіллєвої діяльності спонукає до пошуку нових оптимальних шляхів удосконалення діяльності культурно-дозвіллєвих центрів з урахуванням зростання їхньої ролі в умовах інтеграційних процесів суспільства. Формування нових суспільних відносин актуалізує дослідження проблем соціокультурної сфери, де культура відчуває вплив соціально-політичних і соціально-економічних чинників, водночас безпосередньо відбиваючись на їх розвитку, та стає своєрідним соціальним каталізатором. Зазначено, що філософські аспекти дозвілля визначають його самодостатнім функціонуючим організмом.

Таким чином, глобалізація світової спільноти, посилення конкуренції, поглиблення інформаційних процесів призвели до того, що розвиток культурнодозвіллєвих центрів набув цілеспрямованого характеру. Адже рівень розвитку держави починає оцінюватись, у тому числі, й за діяльністю культурно-дозвіллєвих закладів.

\section{- Список використаних джерел}

Азарян, Е. М., \& Мартынов, И. Ю. (2013). Оценка эффективности разработки стратегии развития и продвижения индустрии развлечений и отдыха. Вісник Донецького Національного університету економіки і торгівлі ім. М. Туган-Барановського, 4(60), 27-34.

Ариарский, М.А.(2008). Социально-культурная деятельность как предмет научного осмысления. Арт-студия «Концерт».

Бестужев-Лада, И. В. (1997). Перспективы развития культуры в проблематике социального прогнозирования. Издательство Санкт-Петербургского гуманитарного университета профсоюзов.

Бойко, О. П. (2011). Культура дозвілля: трансформації та перспективи розвитку у добу глобалізації [Автореферат дисертації доктора філософських наук, Харківський національний педагогічний університет імені Г. С. Сковороди]. 
Бочелюк, В. Й., \& Бочелюк, В. В. (2006). Дозвіллєзнавство. Центр навчальної літератури. Воловик, А. Ф., \& Воловик, А. В. (1999). Педагогіка дозвілля. Харківська державна академія культури.

Гриценко, О. (Ред.). (2001). Багатокультурність і освіта: перспективи запровадження засад полікультурності в системі середньої школи в Україні. УЦКД.

Жаркова, Л. С. (2015). Мотивационное развитие личности в социально-культурном измерении [Монография]. Московский государственный институт культуры.

Каган, М. С. (1996). Философия культуры. Петрополис.

Киселева, Т. Г., \& Красильников, Ю.Д. (2004). Социально-культурная деятельность. Московский государственный университет культуры и искусств.

Максютин, Н. Ф. (2003). Очерки истории досуга (2-е изд.) Медицина.

Маркарян, Э. С. (2000). Науки о культуре и императивы эпохи. К обоснованию ключевой роли знаний о способе социокультурного типа самоорганизации жизни в условиях современного планетарного кризиса: Программный доклад для культурологических чтений. Москва.

Новикова, И. А. (1992). Организация досуга подрастающего поколения в США: традиции и современность [Диссертация доктора педагогических наук, СанктПетербургский государственный институт культуры].

Петрова, І.В.(2011). Культурно-дозвіллєві практики населення сучасної України: тенденції та пріоритети. Культура і сучасність, 1, 108-112.

Піча, В. М. (1990). Культура вільного часу (фрілософрсько-соціологічний аналіз). Світ.

Соколов, Э. В. (1989). Понятие, сущность и основные фуункции культуры. Ленинградский государственный институт культуры.

Царев, В., \& Соколовский, Б. (2011). Дискотека 80-х... Опыты режиссуры общения. Санкт-Петербургский государственный университет культуры и искусств. https:// studfile.net/preview/4164636/

Цимбалюк, Н. М. (2000). Організація та методика культурно дозвіллєвої діяльності (Ч. 1: Теоретичні основи культурно-дозвіллєвої діяльності). Державна академія керівних кадрів культури і мистецтв.

Ядов, В.А. (1986). Социологические методы исследования клубной работы. ВНМЦНТИКПР.

\section{References}

Ariarskii, M. A. (2008). Sotsial'no-kul'turnaya deyatel'nost' kak predmet nauchnogo osmysleniya [Socio-cultural Activities as a Subject of Scientific Understanding]. Artstudiya "Kontsert" [in Russian].

Azaryan, O. M., \& Martinov, I. Y. (2013). Otsenka effektivnosti razrabotki strategii razvitiya i prodvizheniya industrii razvlechenii $\mathrm{i}$ otdykha [Evaluating the Effectiveness of Strategy Development and Promotion of Entertainment and Recreation]. Donetsk National University of Economics and Trade named after Mykhailo Tugan-Baranovsky, 4(60), 27-34 [in Russian].

Bestuzhev-Lada, I. V. (1997). Perspektivy razvitiya kul'tury $v$ problematike sotsial'nogo prognozirovaniya [Prospects for the Development of Culture in the Problems of Social Forecasting]. Izdatel'stvo Sankt-Peterburgskogo gumanitarnogo universiteta profsoyuzov [in Russian]. 
Bocheliuk, V. Y., \& Bocheliuk, V. V. (2006). Dozvillieznavstvo [Leisure Science]. Tsentr navchalnoi literatury [in Ukrainian].

Boiko, O. P. (2011). Kultura dozvillia: transformatsii ta perspektyvy rozvytku u dobu hlobalizatsii [Leisure Culture: Transformations and Development Prospects During Globalisation] [Abstract of DSc Dissertation, H.S. Skovoroda Kharkiv National Pedagogical University] [in Ukrainian].

Hrytsenko, O. (Ed.). (2001). Bahatokulturnist i osvita: perspektyvy zaprovadzhennia zasad polikulturnosti $v$ systemi serednoi shkoly $v$ Ukraini [Multiculturalism and Education: Prospects for Introducing the Principles of Multiculturalism in the Secondary School System in Ukraine]. UTsKD [in Ukrainian].

Kagan, M. S. (1996). Filosofiya kul'tury [Philosophy of Culture]. Petropolis [in Russian].

Kiseleva, T. G., \& Krasil'nikov, Yu. D. (2004). Sotsial'no-kul'turnaya deyatel'nost' [Socio-cultural Activities]. Moskovskii gosudarstvennyi universitet kul'tury i iskusstv [in Russian].

Maksiutin, N. F. (2003). Ocherki istorii dosuga [Essays on the History of Leisure] (2 ${ }^{\text {nd }}$ ed.). Meditsina [in Russian].

Markarian, E. S. (2000). Nauki o kul'ture i imperativy epokhi. K obosnovaniyu klyuchevoi roli znanii o sposobe sotsiokul'turnogo tipa samoorganizatsii zhizni $v$ usloviyakh sovremennogo planetarnogo krizisa [Cultural Sciences and Imperatives of the Era. To Substantiate the Key Role of Knowledge About the Method of the Sociocultural Type of Self-organisation of Life in the Conditions of the Modern Planetary Crisis]: Keynote speech for cultural readings. Moscow [in Russian].

Novikova, I. A. (1992). Organizatsiya dosuga podrastayushchego pokoleniya v SShA: traditsii $i$ sovremennost' [Organisation of Leisure of the Younger Generation in the USA: Tradition and Modernity] [Doctoral Dissertation, St. Petersburg State Institute of Culture] [in Russian].

Petrova, I. V. (2011). Kulturno-dozvillievi praktyky naselennia suchasnoi Ukrainy: tendentsii ta priorytety [Cultural and leisure practices of the population of modern Ukraine: trends and priorities]. Culture and Contemporanerry, 1, 108-112 [in Ukrainian].

Picha, V. M. (1990). Kultura vilnoho chasu (filosofsko-sotsiolohichnyi analiz) [Culture of Free Time (Philosophical and Sociological Analysis)]. Svit [in Ukrainian].

Sokolov, E. V. (1989). Ponyatie, sushchnost' i osnovnye funktsii kul'tury [The Concept, Essence and Basic Functions of Culture]. Leningradskii gosudarstvennyi institut kul'tury [in Russian].

Tcarev, V., \& Sokolovskii, B. (2011). Diskoteka 80-kh... Opyty rezhissury obshcheniya [Disco of the '80s... Experiments of Directing Communication]. St. Petersburg State University of Culture and Arts. https://studfile.net/preview/4164636/ [in Russian].

Tsymbaliuk, N. M. (2000). Orhanizatsiia ta metodyka kulturno dozvillievoi diialnosti [Organibation and Methodology for Cultural Leisure Activities] (Pt. 1: Teoretychni osnovy kulturno-dozvillievoi diialnosti [Theoretical foundations of cultural and leisure activities]). Derzhavin Academy of Culture and Arts Management [in Ukrainian].

Volovik, A. F., \& Volovik, A. V. (1999). Pedahohika dozvillia [Pedagogy of Leisure]. Kharkiv State Academy of Culture [in Ukrainian].

Yadov, V. A. (1986). Sotsiologicheskie metody issledovaniya klubnoi raboty [Sociological Methods of Research Club Work]. VNMTsNTIKPR [in Russian]. 
Zharkova, L. S. (2015). Motivatsionnoe razvitie lichnosti v sotsial'no-kul'turnom izmerenii [Motivational Personality Development in the Socio-cultural Dimension] [Monograph]. Moskovskii gosudarstvennyi institut kul'tury [in Russian].

\title{
- THE PHENOMENON OF CULTURAL AND LEISURE ACTIVITIES: PROBLEM CONCEPTUALISATION
}

\author{
- Olha Shmaiun \\ - PhD student, \\ ORCID: 0000-0002-1863-3581, e-mail: olinka.fedorenko@gmail.com, \\ Kyiv National University of Culture and Arts, \\ Kyiv, Ukraine
}

\section{- Abstract}

The article examines the phenomenon of leisure as a unique phenomenon that contributes to the implementation and development of numerous types and forms of cultural and leisure activities. The purpose of the article is to study the peculiarities of the development of modern cultural and leisure centres of Ukraine in the environment of socio-cultural existence. The methodological basis of the study is the main provisions of cultural studies, sociology of culture, and social psychology, which consider leisure culture as a socio-cultural phenomenon. The scientific novelty consists in defining and clarifying scientific and theoretical approaches to the study of leisure in the framework of foreign and domestic research. Conclusions. The analysis of the process of formation and development of the phenomenon of cultural and leisure activities encourages the search for new optimal ways to improve the activities of cultural and leisure centres. The formation of new social relations actualises the study of the socio-cultural sphere, where culture is influenced by socio-political and socio-economic mechanisms, while directly affecting their development and becomes a kind of social catalyst. In particular, the philosophical aspects of leisure define it as a self-sufficient functioning system. There has also been an increase in scientific developments in leisure pedagogy, substantiation of the conceptual apparatus, principles, functions, main types, and organisational forms used in the practice of leisure activities. The socio-pedagogical aspect of leisure activities is reflected in the infrastructure, content, and leisure preferences to combine different levels of social environment organisation. It is noted that globalisation, increased competition, and deepening of information processes have led to the targeted development of cultural and leisure centres, because the level of state development in the modern world is measured, among other things, by the activities of cultural and leisure institutions.

Keywords: leisure; free time; cultural and leisure activities; interest 


\section{ФЕНОМЕН КУЛЬТУРНО-ДОСУГОВОЙ ДЕЯТЕЛЬНОСТИ: КОНЦЕПТУАЛИЗАЦИЯ ПРОБЛЕМЫ}

\section{- Шмаюн Ольга Юрьевна}

- Аспирантка, ORCID: 0000-0002-1863-3581, e-mail: olinka.fedorenko@gmail.com, Киевский национальный университет культуры и искусств, Киев, Украина

\section{- Аннотация}

В статье исследуется феномен досуга как уникальное явление, способствующее реализации и развитию многочисленных видов и форм культурно-досуговой деятельности. Цель статьи - исследование особенностей развития современных культурно-досуговых центров Украины в среде социокультурного существования. Методологической основой исследования явились основные положения культурологии, социологии культуры и социальной психологии, рассматривающие досуговую культуру как социокультурный феномен. Научная новизна состоит в определении и уточнении научно-теоретических подходов к изучению досуга в рамках зарубежных и отечественных исследовательских работ. Выводы. Анализ процесса формирования и становления феномена культурно-досуговой деятельности побуждает к поиску новых оптимальных путей усовершенствования деятельности культурно-досуговых центров. Формирование новых общественных отношений актуализирует исследование проблем социокультурной сферы, где культура испытывает влияние социально-политических и социально-экономических механизмов, одновременно оказывая непосредственное влияние на их развитие, и становится своеобразным социальным катализатором. В частности, философрские аспекты досуга определяют его самодостаточным функционирующим организмом. Состоялась также активизация научных разработок педагогики досуга, обоснование понятийного аппарата, принципов, функций, основных видов и форм, используемых в практике его проведения. Социально-педагогический аспект разрешительной деятельности находит свое отражение в инфраструктуре, содержании, досуговых предпочтениях для объединения разных уровней организации социальной среды. Отмечено, что глобализация, усиление конкуренции, углубление информационных процессов привели к целенаправленному характеру развития культурно-досуговых центров, ведь уровень развития государства в современном мире оценивается, в том числе, и по деятельности культурно-досуговых учреждений.

Ключевые слова: досуг; свободное время; культурно-досуговая деятельность; интерес 